\title{
Enzim suplementation in the quail (Coturnix coturnix Japonica) diet containing Indigofera Zolingeriana on performance and metabolizable energy
}

\author{
Suharyanti*, Muhammad Ridla, Indah Wijayanti, Rita Mutia \\ Department of Nutrition and Technology, Animal Feed, IPB University, 16680, Bogor, \\ Indonesia
}

Submitted: 11 July 2020, Accepted: 15 January 2021

\begin{abstract}
This study aims to evaluate the effect of protease enzyme supplementation and NSP on feed containing I. Zollingeriana to improve performance and metabolic energy in quails. This study used 192 female quails with a Coturnix-coturnix japonica strain aged 42 days. The experimental design used in this study was a completely randomized design (CRD), with four treatments and four replications, with treatments being R1 = Basal Feed, R2 = Feed containing $10 \%$ I. Zollingeriana, R3 = R1 + protease enzyme, and R4 = R1 + NSP enzyme. The parameters observed in this study were feed consumption, hen day, egg mass production, feed conversion, mortality, and metabolic energy. The results showed that feeding containing $10 \%$ of I. Zollingeriana was able to increase the consumption, decrease the egg mass production, increase feed convertion and reduce the nitrogen retention. The addition of the NSP enzyme can increase quil performance which were fed containing $10 \%$ I. Zollingeriana. The use of NSP and protease enzymes can increase the retention value of quail ration containing I. Zollingeriana leaves.
\end{abstract}

Keywords: Enzymes; Metabolizable energy; I. Zollingeriana; Quail; Performance

\footnotetext{
*Corresponding Author: yanthii100@gmail.com
} 


\section{INTRODUCTION}

Quail is one of the livestock that has begun to be developed to meet the nutritional needs of the community as a source of animal protein. This causes the quail population to increase every year. One of the factors that cause quail to be in demand is because quails are able to produce 250-300 eggs/year with an average weight of 6-16 g / grain (Subekti and Hastuti, 2013; Sezer, 2007). Quail has fast growth, starting from 42 days of age, relatively fast egg production, relatively high generation intervals, and productivity, besides that quail is one of the livestock commodities that are increasingly in demand by Indonesians (Ghazvian et al., 2011).

The feed is an important factor in the poultry industry for the continuity of livestock raising. During maintenance, quail requires adequate protein intake to produce eggs. Sources of protein that are commonly used in the manufacture of feed come from soybean meal and fish meal. Both of these feed ingredients have a high enough price in the market. In 2013, as many as 3.53 million tons of soybean meal were imported to Indonesia to meet the needs of vegetable feed sources in the livestock industry (Ditjen PPHP, 2014). Various attempts have been made to overcome dependence on imported feed ingredients. Import problems can be overcome by maximally utilizing local feed ingredients as poultry feed ingredients. One of them is by utilizing forage-based local feed in the form of legumes as an alternative to a source of vegetable protein. Several types of legume plants have potential as quality forage ingredients because they have complete nutrients (Khamseekhiew et al., 2001; Alam et al., 2007). Indigofera zolingeriana (I. zollingeriana) is a tree legume that has a high production and is available all year round. Indigofera has the potential as a source of poultry feed ingredients because it has a crude protein content of up to $31 \%$ (Abdullah, 2010). The high protein content contained in $I$. zollingeriana indicates that this legume plant can be used as an alternative feed ingredient for poultry. I. zollingeriana has a high protein content but also has a limiting factor when used as poultry feed, namely a high crude fiber content of $10.97 \%-21.40 \%$ (Abdullah and Suharlina, 2010) so that it can reduce digestibility in quail feed.

Another weakness of I. zollingeriana is that it has anti-nutrients in the form of $0.08 \%$ tannins and $0.41 \%$ saponins (Abdullah, 2010). I zollingeriana also has a weakness in the form of a low index of essential amino acids, namely $21.53 \%$ compared to soybean meal of $36.5 \%$ (Palupi, 2014). Increasing the use-value of $I$. zollingeriana which has a weakness in the form of high crude fiber and has several antinutrients can be done by supplementing the NSP enzyme and protease in the ration. Enzymes in the ration can increase digestive enzyme activity so that it can improve digestibility and retention of protein and other food substances such as carbohydrates and fats so as to improve performance (Brenes et al., 2002; Brenes et al., 2003; Pinheiro et al., 2004; Wang et al., 2005; Pourreza et al., 2007). The protease enzyme is an enzyme that helps the process of protein hydrolysis or in other words, the breakdown of protein so that it can be digested by the body.

Non-stretch polysaccharide (NSP) is a complex enzyme that contains most of the mannanase, protease, and several other enzymes whose function is to increase the use-value of some parts of crude fiber and other nutrients that are difficult to digest. Xuan et al., (2001) reported that administering $0.10-0.30 \%$ of the enzyme complex in the ration significantly increased growth and efficiency of ration use. Aderemi et al., (2006) stated that the use of commercial enzymes containing multienzymes was able to improve the appearance of egg production and the efficiency of using rations. The purpose of this study was to evaluate the effect of enzyme administration and enzyme performance on feed rations containing $I$. 
zollingeriana leaf meal to improve feed metabolic energy and performance.

\section{MATERIALS AND METHODS Research Material}

This research was conducted from March to June 2019. The location of this research was in the Poultry Nutrition Field Laboratory (cage C), Faculty of Animal Science IPB. The livestock used were 192 laying quails in the layer phase with a 6week old strain of Coturnix-coturnix japonica. The quail was allocated to 4 treatments and 4 replications (each replication consisted of 12 quails). Provision of food and drinking water ad libitum during the study. The I. zollingeriana leaf flour used in the study was obtained in the FAPET IPB Agrostology Field Laboratory, by drying the top 10 petioles and then drying them in the sun for 2-3 days without separating the leaves from the stalks. The enzyme used is a protease enzyme with the trade name Consentrase-P containing 25,000 units/g and the NSP enzyme under the trade name Superzyme-CS which is a commercial enzyme produced by Canadian Bio-Systems Inc. Calgary, Alberta. The composition of the NSP enzyme is presented in Table 1.

Table 1. Content and concentration of the NSP enzyme

\begin{tabular}{ccc}
\hline Enzyme & Concentration (unit/gram enzyme) & Concentration in feed (unit/Kg feed) \\
\hline Xylanase & 2400 & 600 \\
Glukanase & 300 & 75 \\
Invertase & 1400 & 350 \\
Protease & 2400 & 600 \\
Cellulase & 1000 & 250 \\
Amylase & 24000 & 6000 \\
Mannase & 120 & 30 \\
\hline
\end{tabular}

Source: Canadian Biosystem, 2017

\section{Rations}

The research ration used feed ingredients consisting of corn, rice bran, soybean meal, I. Zollingeriana leaf flour, coconut oil, MBM, CGM, $\mathrm{NaCl}$, premix.
The ration arrangement was made based on the nutrient needs of layer-phase quail with a minimum metabolic energy of $2900 \mathrm{kcal}$ $\mathrm{kg}-1$ and crude protein content of $20 \%-21 \%$ (Table 2).

Table 2. Nutrient requirements for laying quail aged 6 weeks - reject.

\begin{tabular}{lc}
\hline \multicolumn{1}{c}{ Nutrient Content } & Total \\
\hline Crude protein $(\%)$ & $20-21$ \\
Crude Fat $(\%)$ & $2,5-7 *$ \\
Crude Fiber $(\%)$ & $\max 7$ \\
Energy (kcal EM/kg) & $\min 2900$ \\
Ca $(\%)$ & $3,25-4,25$ \\
P $(\%)$ & $0,50-1,00$ \\
Lysine $(\%)$ & 0,86 \\
Methionine $(\%)$ & 0,45 \\
\hline
\end{tabular}

Source: NRC (1994) *; SNI (2008) and Lesson and Summer (2005).

The composition of the feed ingredients and nutrient content of the research quail rations are listed in Table 3. After the ration formulation is carried out, it is continued with ration testing using the proximate method, titrimetry for $\mathrm{Ca}$ and $\mathrm{P}$ analysis and gross energy with a calorimeter bomb. The protease enzymes and NSP were mixed into the ration according to the treatment. The finished research ration was 
then analyzed at the Laboratory of Nutrition and Feed Technology, Faculty of Animal Science IPB.

\section{Research Procedure \\ Maintenance and Performance Measurement}

Quail rearing is carried out for 90 days with a period of collecting eggs for 66 days (aged 44 days - 90 days). At the beginning of maintenance, the quails were weighed and divided into 16 treatment cages (4 treatments, 4 replications). During the adaptation period, quails were given vitastress $(0.5 \mathrm{~g} /$ liter $)$ which was mixed into drinking water for 7 days.

The treated feed and drinking water were given ad libitum. The rest of the feed is weighed every week. In the laying period, egg collection is carried out every day, namely in the morning. The variables measured were ration consumption, egg mass production, ration conversion, mortality, and percent hen day (\%).

\section{Measurement of Feed Metabolic Energy}

Metabolic energy measurements used a modified Farrel (1978) method which was modified and carried out at the end of maintenance (92-94 days). A total of 75 quails were distributed into the metabolic cage. Each cage contains 5 quails. Before the quail is put into the metabolic cage, the weight is first weighed. On the first day, all quails were given treatment feed for 1 day for the adaptation period. On the second day, all the quails were fasted for 24 hours to neutralize the digestive tract from the previous feed while still given drinking water ad libitum.

Table 3. Composition of feed ingredients and nutrient content of quail rations during the study

\begin{tabular}{|c|c|c|}
\hline Feed Ingredients & R1 (\%) & $\mathrm{R} 2(\%)$ \\
\hline Yellow Corn & 56,50 & 55,00 \\
\hline Rice Bran & 7,41 & 3,69 \\
\hline Soybean Meal & 10,91 & 7,90 \\
\hline indigofera leaf powder & 0 & 10,00 \\
\hline Coconut oil & 2,10 & 2,10 \\
\hline MBM & 7,80 & 6,51 \\
\hline CGM & 7,00 & 6,17 \\
\hline $\mathrm{NaCl}$ & 0,20 & 0,30 \\
\hline $\mathrm{CaCO} 3$ & 7,55 & 7,80 \\
\hline Premix & 0,50 & 0,50 \\
\hline DL-Methionine & 0,03 & 0,03 \\
\hline Total & 100 & 100 \\
\hline \multicolumn{3}{|l|}{ Nutrient Content } \\
\hline Dry matter $(\%)^{*}$ & 86,36 & 87,75 \\
\hline Gross energy $\left(\mathrm{Kkal} \mathrm{Kg}^{-1}\right)^{* *}$ & 3372 & 3362 \\
\hline Crude protein $(\%)^{*}$ & 21,29 & 20,74 \\
\hline Crude fiber $(\%)^{*}$ & 1,41 & 5,41 \\
\hline Crude fat $(\%)^{*}$ & 1,12 & 2,00 \\
\hline Calsium $(\%)^{* *}$ & 6,60 & 5,10 \\
\hline Phosphorus $(\%)^{* *}$ & 0,68 & 0,40 \\
\hline
\end{tabular}

Note: $\mathrm{R} 1$ = Basal ration, $\mathrm{R} 2$ = ration containing $10 \%$ leaf meal of I. Zollingeriana.

* Results of proximate analysis at the Laboratory of Nutrition and Feed Technology, Animal Husbandry IPB, ** Results of analysis at the Laboratory of the Animal Research Institute (BALITNAK) - Ciawi.

On the third day, all the fasted quail are weighed to find out the weight of the quail. A total of 60 quails were fed according to treatment (4 treatments $\times 3$ replications $\mathrm{x} 5$ heads) as much as 7 grams for 2 hours. The remaining feed is then 
weighed to determine the amount of feed consumed. The treatment on the third day was repeated for 3 days. The excreta samples were collected for 66 hours, while in the endogenous metabolic energy measurement, 15 quails that had been fasted for 24 hours have fasted again for 48 hours while still giving drinking water ad libitum, then the excreta could be collected.

During excreta collection, every 2 hours the excreta was sprayed with $\mathrm{H} 2 \mathrm{SO} 4$ solution with a concentration of $0.01 \mathrm{~N}$ until the time limit for the excreta collection was complete. The collected excreta were weighed and then put in the freezer for 24 hours. The excreta is removed from the freezer and the thawing process is carried out. The excreta was dried in an oven at 60 ${ }^{\circ} \mathrm{C}$ for 48 hours. The dry excreta samples were cleaned of the remaining hairs and ground using a mortar.

The fine excreta samples were then tested using a bomb calorimeter (Parr 1261® Bomb Calorimeter, Illinois) to determine the gross energy produced. The variables measured based on Sibbald and Wolynetz (1985) are pseudo metabolic energy (EMs), pure metabolic energy (EMM), nitrogen corrected pseudo metabolic energy (EMSn), and nitrogen corrected pure metabolic energy (EMMn).

\section{Research Design and Data Analysis}

The research design used in this study was a completely randomized design (CRD). The number of treatments was 4 treatments and 4 replications. Each replication consisted of 12 laying quails. The treatment in this study consisted of:

$\mathrm{R} 1$ : Basal ration,

R2: The ration contains $10 \%$ leaf meal of I. zollingeriana.

R3: R2 + Protease enzyme

R4: R2 + NSP Enzyme.

The data analysis used in this study is the Analysis of Variance (ANOVA). The research data obtained, if significantly different, then proceed with the DUNCAN test.

\section{RESULT AND DISCUSSION Performance}

The use of $10 \%$ leaves of $I$. zollingeriana in the ration significantly $(\mathrm{P}$ $<0.01$ ) increased consumption of laying quail. The addition of NSP enzymes significantly $(\mathrm{P}<0.01)$ reduced consumption of laying quails which were fed $10 \% I$. zollingeriana. Administration of protease enzymes in laying quail feed containing $10 \%$ leaves of I. zollingeriana did not affect the level of consumption of laying quail. The performance of laying quail was not affected by the treatment of $I$. zollingeriana. The average performance data of quails fed with Indigofera sp and enzymes are presented in Table 4 . The consumption of quail during the study ranged from $22.49 \mathrm{~g} / \mathrm{head} /$ day. $23.87 \mathrm{~g} / \mathrm{head} / \mathrm{day}$. The amount of quail feed consumption is higher than Slamet's (2014) research with consumption of 22.77 $\mathrm{g} /$ head/day.
The use of $10 \%$ leaves of $I$. zollingeriana in rations significantly $(\mathrm{P}$ $<0.01)$ increased ration consumption. The increase in feed consumption was due to the high crude fiber feed, namely $5.41 \%$ so that the digestibility of the ration would decrease as a result of which the nutrient needs of the quails were not met. Quail will continue to increase its feed consumption to meet these nutrient needs. The use of the NSP enzyme was able to reduce the consumption of quail rations containing $I$. zollingeriana leaves because the use of NSP enzymes could help the digestion process of feed containing $I$. zollingeriana leaves. The decrease in feed consumption indicates that the quail stopped eating because their nutrient needs began to be fulfilled. The NSP enzyme is able to break down crude fibers with complex structures into simpler compounds so that they are more easily absorbed by the body. In addition, the NSP enzyme contains a 
protease enzyme of 2400 units/gram so that it can increase protein digestibility as evidenced by the increase in nitrogen retention as shown in Table 5, which increases the nitrogen retention value by $11.28 \%$. In addition to increasing the nitrogen retention value, the use of the NSP enzyme also tends to increase metabolic energy although it is not statistically significant as shown in Table 6.NSP enzyme is better used in quail rations containing $I$. zollingeriana compared to protease enzymes because the NSP enzyme contains several enzyme components, namely xylanase, glucanase, invertase, protease, cellulase, amylase, mannanase.

Table 4. The average performance of quail fed with Indigofera sp and enzymes.

\begin{tabular}{lcccc}
\hline \multicolumn{1}{c}{ Parameter } & $\mathrm{R} 0$ & $\mathrm{R} 1$ & $\mathrm{R} 2$ & $\mathrm{R} 3$ \\
\hline Consumption (g/head/day) & $22,49 \pm 0.38^{\mathrm{A}}$ & $23,87 \pm 0,29^{\mathrm{C}}$ & $23,84 \pm 0,26^{\mathrm{C}}$ & $23,21 \pm 0,51^{\mathrm{B}}$ \\
Hen Day (\%) & $39,71 \pm 12.76$ & $32,73 \pm 2,78$ & $33,84 \pm 0,87$ & $34,46 \pm 6,10$ \\
Egg Mass Production (g/head) & $317,30 \pm 49.31^{\mathrm{A}}$ & $154,29 \pm 40,52^{\mathrm{B}}$ & $169,90 \pm 34,33^{\mathrm{B}}$ & $219,87 \pm 19,92^{\mathrm{B}}$ \\
Ration Conversion & $6,78 \pm 3.28^{\mathrm{A}}$ & $13,64 \pm 3,39^{\mathrm{C}}$ & $12,17 \pm 2,55^{\mathrm{BC}}$ & $8,93 \pm 0,96^{\mathrm{AB}}$ \\
Mortality (\%) & $8,33 \pm 0.11$ & $12,49 \pm 8,34$ & $10,42 \pm 4,17$ & $8,33 \pm 0,12$ \\
\hline
\end{tabular}

Information: $\mathrm{R} 1$ = basal ration, $\mathrm{R} 2=$ ration containing $10 \%$ leaf meal I. Zollingeriana, $\mathrm{R} 3=$ ration containing $10 \%$ leaf meal $I$. zollingeriana plus protease enzyme, R4 = ration containing $10 \%$ leaf meal I. zollingeriana plus enzymes NSP. Different capital letters in the same column show very significant differences $(\mathrm{P}<0.01)$.

The value of hen day production in this study was 32.73 to 39.71 . The hen day value is lower than the hen day value according to Sipayung (2012), namely $51.98 \%$ to $59.29 \%$. The value of laying quail hen day is not influenced by the treatment of I. zollingeriana leaves. The hen day of laying quails is influenced by several factors, namely the age of the quail, age at first laying eggs, and feed protein content (North and Bell, 1992). The feed-in each treatment given in this study was Iso protein so that it did not affect the hen day production.

The value of egg mass production during the study ranged from $154.29 \mathrm{~g} /$ head to $317.30 \mathrm{~g} /$ head. The value obtained is not much different from the research (Faradillah, 2015) which is $284.33 \mathrm{~g} /$ head $391.71 \mathrm{~g} /$ head. The decline in mass production of quail eggs fed with $I$. zollingeriana leaves was caused by high crude fiber and low quality of ration protein. High crude fiber causes a decrease in the digestibility of feed nutrients and disruption of the digestive organs. The high content of crude fiber in the indigestible ration causes an increase in nutrient absorption by the digestive tract, so that nutrient absorption is shorter and less optimal which results in decreased metabolic processes towards nutrient needs (Choct et al, 1995; Mathlouthi et al., 2002). The quality of the ration protein affects egg weight because protein is the main raw material for making albumin or egg white. I. zollingeriana leaves have poor protein quality compared to soybean meal because the essential amino acid index is lower than soybean meal (Palupi, 2014). Neither protease nor NSP was able to increase egg mass production. This is presumably due to a deficiency of several essential amino acids in the formation of albumin. The function of enzymes only improves the digestibility of the ration by helping the process of breaking down several nutrients including protein into a simpler form, not as an ingredient for essential amino acid supplementation.

The increase in the feed conversion value of quail fed rations containing $I$. zollingeriana leaves was due to the high value of the ration crude fiber and the low quality of its protein. The higher conversion value indicates that the digestibility of the feed is low. The high content of crude fiber in the ration makes the digestive organs in the livestock body work harder because crude fiber is difficult to digest and is utilized by the monogastric. The 
composition of crude fiber compounds which are complex and difficult to degrade makes crude fiber difficult to digest by the body either mechanically or enzymatically. Provision of protease enzymes and NSP was able to improve the consumption of quail feed which was given $10 \%$ leaves of $I$. zollingeriana. This is because enzymes help the digestive process in the body. The NSP enzyme helps the process of degradation of crude fiber in the body into simpler compounds that are easily absorbed by the body and used as an energy source. Protease enzymes help the process of protein hydrolysis. Protease enzymes help the process of cutting polypeptides into simple peptides so that protein is more easily absorbed by the body. Mortality of laying quails fed I. zollingeriana leaf feed had no significant effect. This is because all quails that are kept are healthy quails. The temperature and humidity of the coop are always kept in a relatively comfortable state for the quails. The cage used is always cleaned so that the quail are not susceptible to disease. The crude fiber content given to quail in all treatments is still at a safe level for the quails so that it does not interfere with the health of the quail.

\section{Retention of Nitrogen and Metabolic Energy}

The use of $10 \%$ leaves of $I$. zollingeriana in the ration significantly $(\mathrm{P}$ $<0.05)$ decreased nitrogen retention. The addition of protease enzymes and NSP enzymes significantly $(\mathrm{P}<0.05)$ was able to increase the nitrogen retention value of quail rations containing $10 \%$ leaves of $I$. zollingeriana. The use of the protease enzyme was able to increase nitrogen retention until it reached the same value as the basal ration. Metabolic energy was not affected by the feeding of I. zollingeriana leaves in the ration. The data on nitrogen retention and metabolic energy of laying quails are shown in Table 5.

Table 5. Nitrogen retention and metabolic energy of quail fed containing I. zollingeriana and enzymes.

\begin{tabular}{ccccc}
\hline Parameter & R1 & R2 & R3 & R4 \\
\hline Retention & & & & \\
Nitrogen (\%) & $89,44 \pm 2,89^{\mathrm{b}}$ & $59,57 \pm 0,44^{\mathrm{a}}$ & $91,04 \pm 7,74^{\mathrm{b}}$ & $70,85 \pm 2,83^{\mathrm{ab}}$ \\
EMS (Kcal kg-1) & $2113,19 \pm 77,17$ & $1752,88 \pm 398,62$ & $1907,35 \pm 80,75$ & $1807,32 \pm 280,11$ \\
EMM (Kcal kg-1) & $2680,50 \pm 45,68$ & $2621,67 \pm 239,06$ & $2805,46 \pm 52,28$ & $2628,31 \pm 257,32$ \\
EMSn (Kcal kg-1) & $2104,45 \pm 77,45$ & $1745,14 \pm 398,84$ & $1896,66 \pm 80,62$ & $1799,72 \pm 278,21$ \\
EMMn (Kcal kg-1) & $2851,76 \pm 45,73$ & $2613,92 \pm 238,75$ & $2794,77 \pm 51,76$ & $2620,70 \pm 255,09$ \\
\hline
\end{tabular}

Information: $\mathrm{R} 1$ = basal ration, $\mathrm{R} 2=$ ration containing $10 \%$ leaf meal I. Zollingeriana, $\mathrm{R} 3=$ ration containing $10 \%$ leaf meal $I$. Zollingeriana plus protease enzyme, $\mathrm{R} 4=$ ration containing $10 \%$ leaf meal I. Zollingeriana plus NSP enzyme. EMS = pseudo metabolic energy, EMM = pure metabolic energy, EMSn = nitrogen corrected pseudo metabolic energy, EMMn = nitrogen corrected pseudo metabolic energy. Different letters in the same column indicate significant differences $(\mathrm{P}<0.05)$.

The decrease in nitrogen retention value in quail fed a ration containing $10 \%$ leaves of $I$. zollingeriana indicated the low protein digestibility of the ration. This decrease occurred because the protein quality of the I. zollingeriana leaf meal was not as good as soybean meal (Palupi, 2014). The use of the protease enzyme was the best treatment to increase the nitrogen retention value of laying quails which were fed with $10 \%$ I. zollingeriana leaves. Protease enzymes help the process of breaking down proteins into simpler compounds so that they are easily absorbed by the body. The use of the protease enzyme was very effective in overcoming the problem of low protein digestibility in quails that were fed a diet containing $10 \%$ leaves of $I$. zollingeriana. The use of the NSP enzyme is not as good as the protease enzyme in increasing the retention of laying quail nutrition because the protease concentration 
in this NSP complex enzyme is lower, namely 2500 units / g, compared to the pure protease enzyme, which is 25000 units / $\mathrm{g}$.

The pseudo-metabolic energy, pure metabolic energy, nitrogen-corrected pseudo-metabolic energy, and nitrogencorrected pure metabolic energy were not affected by the treatment of feed containing I. zollingeriana in quails. There was a tendency of decreasing metabolic energy value data on rations containing $I$. zollingeriana compared to basal feed. This decrease occurred due to the low quality of I. zollingeriana protein and its relatively high crude fiber content.

The limiting factor in I. zollingeriana causes the digestibility of the feed to be obstructed so that the metabolic energy in the body will be less. The use of enzymes tends to increase the value of metabolic energy because the use of proteases can increase nitrogen retention and the use of NSP enzymes that contain proteases and mannanases can increase the digestibility of protein and fiber. Non-starch polysaccharides, if broken down and utilized by the body, will be used by the body as additional energy, so that metabolic energy will increase with the addition of the enzyme NSP.

\section{CONCLUSIONS}

The use of I. zollingeriana leaf meal as much as $10 \%$ in the ration can reduce the performance of laying quails and reduce the nitrogen retention value of quails. The decrease in the performance value can be increased by the use of the NSP enzyme while the decrease in the nitrogen retention value can be increased by the use of the enzyme protease and NSP. The use of $I$. zollingeriana leaves does not affect metabolic energy value.

\section{REFERENCES}

Abdullah, L. (2010). Herbage production and quality of shrub indigofera treated by different concentration of foliar fertilizer. Media Peternakan, 33(3), 169-175. https://doi.org/10.5398/med p et.2010.33.3.169

Abdullah, L., \& Suharlina. (2010). Herbage yield and quality of two vegetative parts of indigofera at different times of first regrowth defoliation. Media Peternakan, 33(1), 44-49.

Aderemi, F., Lawal, O., Ladokun, O., \& Adeyemo, G. (2006). Effect of enzyme supplemented cassava root sieviate on egg quality gut morphology and performance of egg type chickens. International Journal of Poultry Science, 5(6), 526-529. https://doi. org/10.3923/ijps.2006.526 .529

Alam, M. R., Amin, M. R., Kabir, A. K. M. A., Moniruzzaman, M., \& McNeill, D. M. (2006). Effect of tannins in acacia nilotica, albizia procera and sesbania acculeata foliage determined in vitro, in sacco, and in vivo. AsianAustralasian Journal of Animal Sciences, 20(2), 220-228. https://doi. org/10.5713/ajas.2007.220

Brenes, A., Marquardt, R. R., Guenter, W., \& Viveros, A. (2002). Effect of enzyme addition on the performance and gastrointestinal tract size of chicks fed lupin seed and their fractions. Poultry Science, 81(5), 670-678. https://doi. org/10.1093/ps/81.5.670

Brenes, Agustín, Viveros, A., Arija, I., Centeno, C., Pizarro, M., \& Bravo, C. (2003). The effect of citric acid and microbial phytase on mineral utilization in broiler chicks. Animal Feed Science and Technology, 110(14), 201-219. https://doi.org/10.1016/ S0377-8401(03)00207-4

Choct, M., Hughes, R. J., Trimble, R. P., Angkanaporn, K., \& Annison, G. (1995). Non-starch polysaccharidedegrading enzymes increase the performance of broiler chickens fed wheat of low apparent metabolizable energy. Journal of Nutrition, 125(3), 485-492. https://doi.org/10.1093/jn/ 125.3.485

Direktorat Jendral Pengolahan dan Pemasaran Hasil Pertanian. (2014). 
Kementerian Pertanian Republik Indonesia. Jurnal statistik Ekspor Impor Komoditas Pertanian.

Faradillah, F., Mutia, R., \& Abdullah, L. (2015). Substitution of soybean meal with indigofera zollingeriana top leaf meal on egg quality of cortunix cortunix japonica. Media Peternakan, 38(3), 192-197. https://doi.org/10.539 8/medpet.2015.38.3.192

Ghazvinian, K., Irani, M., Jamshidi, R., \& Mirzaei-aghsaghali, A. (2011). The effect of energy to protein ratio on production performance and characteristics of Japanese quail eggs. Annals of Biological Research, 2(2).

Khamseekhiew, B., Liang, J. B., Wong, C. C., \& Jalan, Z. A. (2001). Ruminal and Intestinal digestibility of some tropical legume forages. Asian-Australasian Journal of Animal Sciences, 14(3), 321-325. https://doi.org/10.5713/ajas. 2001.321

Leeson, S., \& Summers, J. (2005). Comercial Poultry Nutrition (G. Ontario (ed.); 3rd ed.). Departement of Animal and Poultry Science University of Guelph.

Mathlouthi, N., Mohamed, M. A., \& Larbier, M. (2003). Effect of enzyme preparation containing xylanase and B-glucanase on performance of laying hens fed wheat/barley- or maize/soybean meal-based diets. British Poultry Science, 44(1), 60-66. https://doi.org/10.1080/00071660310 00085374

North, M. O., \& Bell, D. (1992). Comercial Chicken Production Manual (4th ed.). An AVI Book Published by Nostrand Reinhold.

NRC. (1994). Nutrien Requirements of Poultry (9th ed.). National Academy Press.

Palupi, R., Abdullah, L., Astuti, D. A., \& Sumiati. (2014). High antioxidant egg production through substitution of soybean meal by indigofera sp., top leaf meal in laying hen diets. International Journal of Poultry
Science, 13(4), 198-203. https://doi. org/10.3923/ijps.2014.198.203

Palupi, Rizki, Abdullah, L., Astuti, D. A., \& Sumiati. (2015). Potential and utilization of Indigofera sp shoot leaf meal as soybean meal substitution in laying hen diets. Jurnal Ilmu Ternak Dan Veteriner, 19(3), 210-219. https: //doi.org/10.14334/jitv.v19i3.1084

Pourreza, J., Samie, A. H., \& Rowghani, E. (2007). Effect of supplemental enzyme on nutrient digestibility and performance of broiler chicks fed on diets containing triticale. International Journal of Poultry Science, 6(2), 115117. https://doi.org/10.3923/ijps.2007 .115 .117

Sezer, M. (2007). Heritability of exterior eggs quality traits in japanese quail. $J$ Appl Biol Sci, 6(2), 115-117.

Sipayung, P. P. (2012). Performa produksi dan kualitas telur puyuh (Coturnixcoturnix japonica) pada kepadatan kandang yang berbeda. In Fakultas Peternakan, Institut Pertanian Bogor.

Standar Nasional Indonesia. (2008). Telur Ayam Segar untuk Konsumsi. Badan Standarisasi Nasional.

Subekti, E., \& Hastuti, D. (2013). Budidaya puyuh (coturnix coturnic japonica) di pekarangan sebagai sumber protein hewani dan penambah income keluarga. MEDIAGRO, 9(1), 1-10.

Wang, S.-H. (2005). Effect of superoxide dismutase and malondialdehyde metabolic changes on carcinogenesis of gastric carcinoma. World Journal of Gastroenterology, 11(28), 43054310. https://doi.org/10.3748/wjg.v11 .i28.4305

Xuan, Z. N., Kim, J. D., Lee, J. H., Han, Y. K., Park, K. M., \& Han, I. K. (2001). Effects of enzyme complex on growth performance and nutrient digestibility in pigs weaned at 14 days of age. Asian-Australasian Journal of Animal Sciences, 14(2), 231-236. https:// doi.org/10.5713/ajas.2001.231 